\title{
Phaeodaria from the northwestern Pacific, with description of a new species, Challengeron tochilinae
}

\author{
A.V. Chernyshev \\ National Scientific Center of Marine Biology, Far Eastern Branch, Russian Academy of Sciences, \\ Vladivostok 690041, Russia. \\ Far Eastern Federal University, Vladivostok 690600, Russia. \\ E-mail:nemertea1969@gmail.com
}

ABSTRACT: New data on the morphological variability and scanning electron microphotographs of the following species are provided: Aulographis japonica Nakamura, Tuji et Suzuki, 2013, Protocystis vicina Reshetnjak, 1952, and Haeckeliana megalodonta Reshetnjak, 1952. Aulographis japonica has been first found in the northwestern Sea of Japan. It is suggested that Protocystis ornitocephala Reshetnjak, 1952 and P. vicina may be synonyms. A new species, Challengeron tochilinae sp.n., is described from specimens collected in the Sea of Okhotsk.

How to cite this article: Chernyshev A.V. 2019. Phaeodaria from the northwestern Pacific, with description of a new species, Challengeron tochilinae // Invert. Zool. Vol.16. No.4. P.393-397. doi: 10.15298/invertzool.16.4.06

KEY WORDS. Phaeodarians, Aulographis, Haeckeliana, Protocystis, Challengeron, Sea of Japan, Sea of Okhotsk.

\section{Phaeodaria из северо-западной Пацифики с описанием нового вида, Challengeron tochilinae}

\section{А.В. Чернышев}

Национальный научный центр морской биологии им. А.В. Жирмунского ДВО РАН, Владивосток 690041, Россия.

Дальневосточный федеральный университет, Владивосток 690600, Россия.

E-mail:nemertea1969@gmail.com

РЕЗЮМЕ: Приведены новые данные об изменчивости морфологии, а также электронно-микроскопические фотографии Aulographis japonica Nakamura, Tuji et Suzuki, 2013, Protocystis vicina Reshetnjak, 1952 и Haeckeliana megalodonta Reshetnjak, 1952. Aulographis japonica впервые обнаружен в северо-западной части Японского моря. Сделано предположение, что Protocystis ornitocephala Reshetnjak, 1952 и $P$. vicina могут быть синонимами. Описан новый вид, Challengeron tochilinae sp.n., собранный в Охотском море.

Как цитировать эту статью: Chernyshev A.V. 2019. Phaeodaria from the northwestern Pacific, with description of a new species, Challengeron tochilinae // Invert. Zool. Vol.16. No.4. P.393-397. doi: 10.15298/invertzool.16.4.06

КЛЮЧЕВЫЕ СЛОВА. Phaeodarians, Aulographis, Haeckeliana, Protocystis, Challengeron, Японское море, Охотское море. 

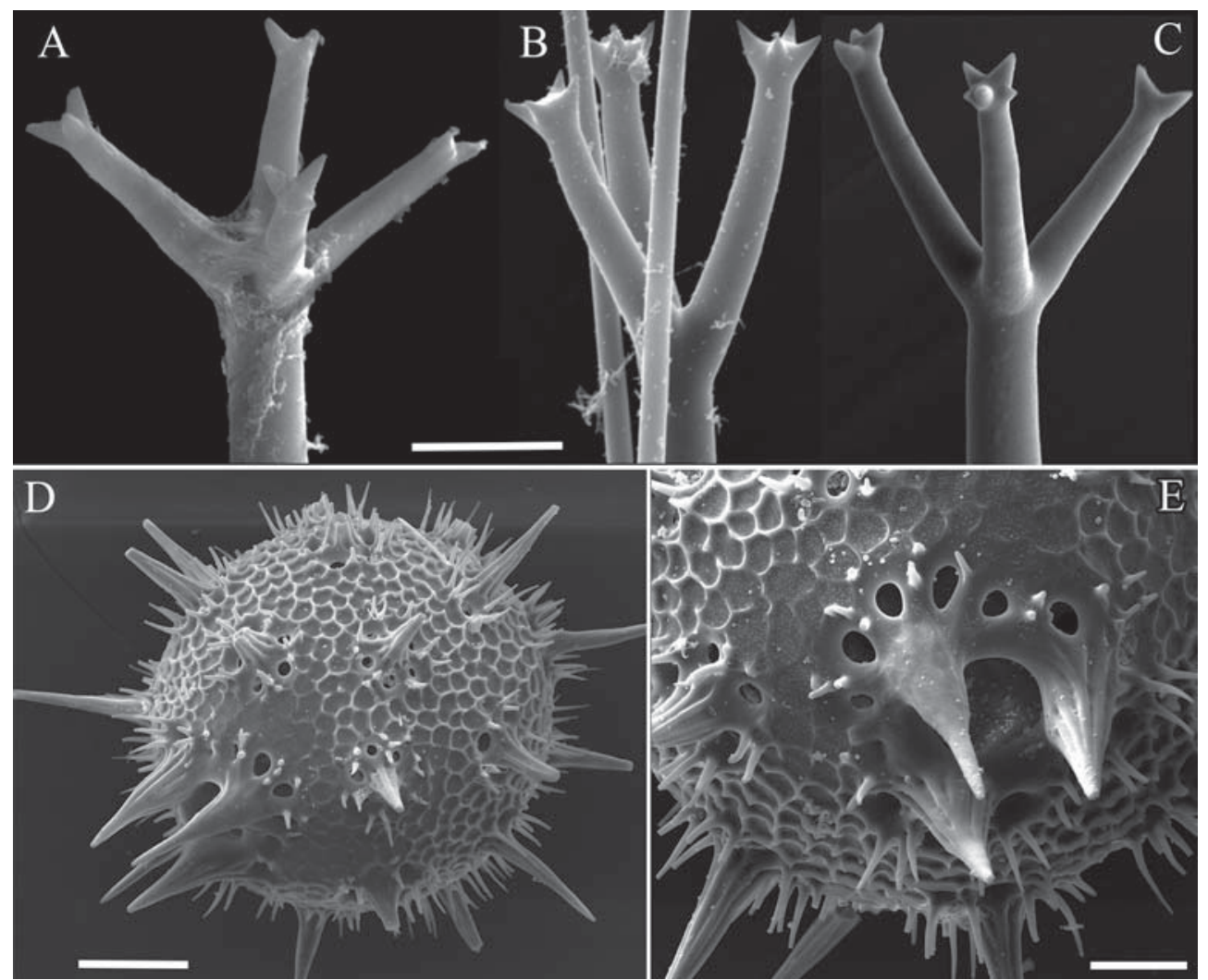

Fig. 1. SEM structures of two phaeodarian species. A-C - Aulographis japonica, terminal branches of the radial spines; D, E - Haeckeliana megalodonta, whole shell. Scale bars: A-C - $10 \mu \mathrm{m}, \mathrm{D}-100 \mu \mathrm{m}, \mathrm{E}-$ $50 \mu \mathrm{m}$.

Рис. 1. СЭМ структура двух видов феодарий. А-C - Aulographis japonica, терминальные ветви радиальных игл; D, E - Haeckeliana megalodonta, раковина. Масштаб: A-C - 10 мкм, D - 100 мкм, $\mathrm{E}-50$ мкм.

\section{Introduction}

Phaeodarians from the northwestern Pacific have been exhaustively studied by Reshetnjak (1966), where she covered 97 species. Reshetnjak (1966) described 15 new species. Unfortunately, the original materials studied by Vitaliya V. Reshetnjak have been lost. Although Reshetnjak (1966) did not find phaeodarians in the Sea of Japan, recent works of Japanese researchers greatly expanded our knowledge of the phaeodarians from the northwestern Pacific (Okazaki et al., 2004, 2005; Ishitani, Takahashi, 2007), including the description of several new species from the Sea of Japan (Nakamura et al., 2013, 2015a). The present report provides a description of a new species, as well as new data on some other phaeodarians so far not recorded elsewhere.

\section{Material and methods}

The plankton samples used for this report were collected during two research cruises aboard the R/V 'Akademik Lavrentyev' and R/ $\mathrm{V}$ 'Sonne', and fixed in $95 \%$ ethanol. The phaeodarians were studied using scanning electron microscopy (SEM; Zeiss Evo 40). The specimens have been deposited at the Museum of the National Scientific Center of Marine Biology, Vladivostok (MIMB). 


\section{Results}

Family Aulacanthidae Haeckel, 1887 Aulographis japonica Nakamura, Tuji et Suzuki, 2013

Fig. 1 A-C.

Material: ca. 50 specimens (MIMB 36541 and 36542), Sea of Japan, R/V 'Akademik

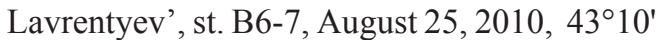
$\mathrm{N}, 135^{\circ} 00^{\prime} \mathrm{E}$, epibenthic sledge, depth 1001$1011 \mathrm{~m}$; st. B7-7, August 25, 2010, 43ำ1' N, $135^{\circ} 04^{\prime} \mathrm{E}$, epibenthic sledge, depth 470-528 m.

REMARKS. The specimens under study are very similar to Aulographis japonica. However, the radial spines form 3 (very rarely 2 or 4 ) terminal branches with 1-5 (usually 3-4) peripheral teeth and without an apical tooth. The original description of $A$. japonica indicates $3-$ 4 terminal branches, 4-6 peripheral teeth, and sometimes one apical tooth (Nakamura et al., 2013). Since in our specimens the shape of the peripheral teeth is similar to those in A. japonica from the eastern Sea of Japan, a character unique for this species, I suggest that these differences are within the limits of intraspecific variation.

DISTRIBUTION. Up to date, recorded in the Sea of Japan only, where it is the only species of the genus Aulographis. First record for the northwestern Sea of Japan.

ECOLOGICALDATA. The sampling method used precludes from establishing the depth range of this species with certainty. The specimens could have been collected in the nearbottom layer, or captured during recovery of the sledge in shallower waters. According to Nakamura et al. (2013), in terms of zooplankton biomass, below $250 \mathrm{~m}$ this is the second most important species.

Family Circoporidae Haeckel, 1879

Haeckeliana megalodonta Reshetnjak in Dogel et Reshetnjak, 1952

Fig. 1 D, E.

MATERIAL: one shell, northwestern Pacific, near the Kuril-Kamchatka Trench, R/V
'Sonne', st. 2-9, August 02, 2012, 46 $13.60^{\prime}$ N, $155^{\circ} 33.42^{\prime}$ E, epibenthic sledge, depth $4866 \mathrm{~m}$.

REMARKS. After Reshetnjak's works (Dogel, Reshetnjak, 1952; Reshetnjak, 1966), this species has never been recorded again. The shell dimensions and the arrangement of the pores and spines match the description of Haeckeliana megalodonta (Dogel, Reshetnjak, 1952), but our specimen has 3 peristomal teeth (rather than 4-5). Since Reschetnjak's materials for this species were scarce (approximately 5-6 specimens), I consider that this difference is within the limits of intraspecific variation.

DISTRIBUTION. Northwestern Pacific Ocean at depths of 8000-4000 m, 4000-2000 $\mathrm{m}$, and 1000-200 m; Sea of Okhotsk at depths of 3395-0 m.

Family Challengeriidae Murray, 1876 emend. Takahashi, 1991

Challengeron tochilinae Chernyshev, sp.n. Fig. 2A-D. 1, WNP5

Challengeriidae sp. 2 - Nakamura et al., 2015b: Fig.

MATERIAL: Holotype (MIMB 38852) (Fig. 2A), Sea of Okhotsk, R/V 'Akademik Lavrentyev', st. 2, May 12, 2013, 5400' N, $146^{\circ} 25^{\prime} \mathrm{E}$, Juday's big plankton net, from 1380 $\mathrm{m}$ to surface (total bottom depth $1436 \mathrm{~m}$ ); 2 paratypes, (MIMB 38853).

DESCRIPTION. Shell subcircular (87-95 $\mu \mathrm{m}$ long, 93-99 $\mu \mathrm{m}$ wide), slightly compressed, with three straight spines: one longer (72-75 $\mu \mathrm{m}$ long) on apical pole and two shorter (56-61 $\mu \mathrm{m}$ long) on the dorsal and ventral margins. Shell surface with numerous regularly arranged pores and irregular tubercles $0.3-0.5 \mu \mathrm{m}$ in diameter (Fig. 2C). Peristome smooth, 58-61 $\mu \mathrm{m}$ long, and laterally compressed, with 3 oral teeth, one larger, straight, 43-48 $\mu \mathrm{m}$ long, and two shorter, slightly curved, 16-17 $\mu \mathrm{m}$ long (Fig. 2B). Amphora structures of shell wall subspherical (Fig. 2D).

ETYMOLOGY. This species is named in memory of Dr. Svetlana V. Tochilina for her contributions to the investigation of Cenozoic radiolarians. 

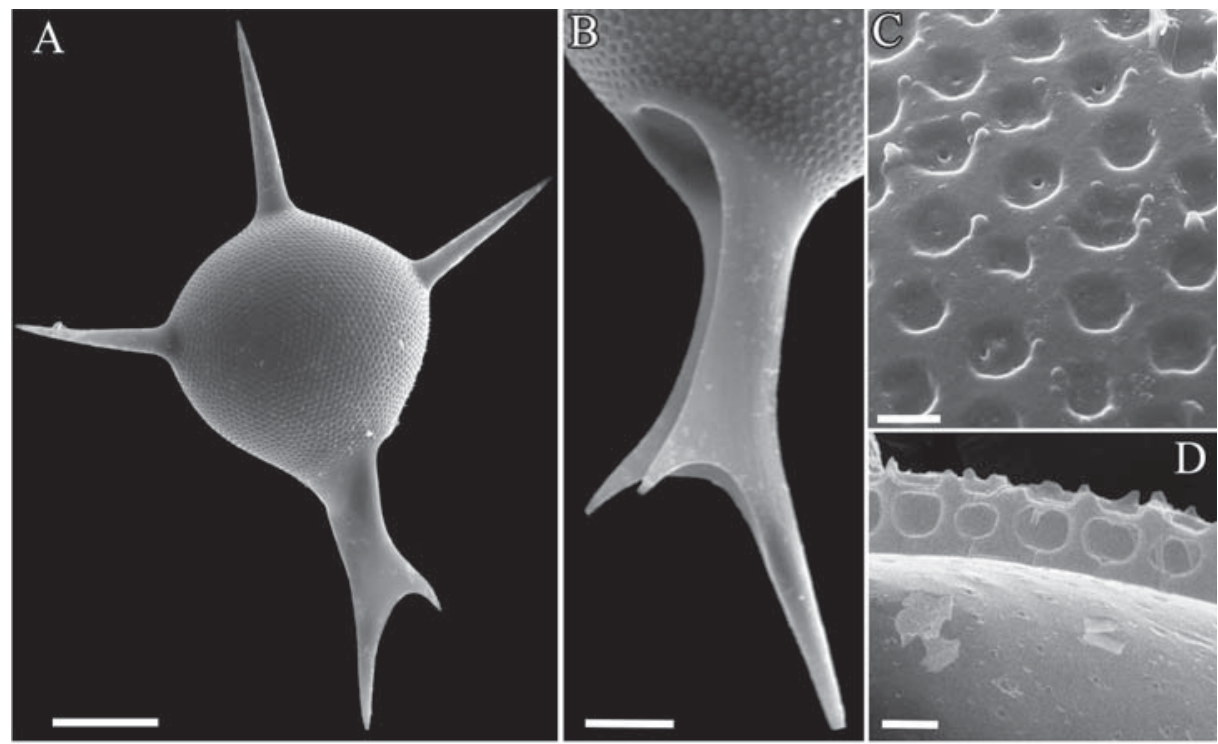

Fig. 2. Challengeron tochilinae sp.n., SEM images of the shells. A - holotype, B-D - paratypes (B peristome, C - external surface, D - shell microstructure). Scale bars: A - $40 \mu \mathrm{m}, \mathrm{B}-20 \mu \mathrm{m}, \mathrm{C}, \mathrm{D}-2 \mu \mathrm{m}$. Рис. 2. Challengeron tochilinae sp.n., СЭМ структура раковин. А - голотип, В-D - паратипы (B перистом, C - наружная поверхность, D - микроструктура раковины). Масштаб: A - 40 мкм, В 20 мкм, C, D - 2 мкм.
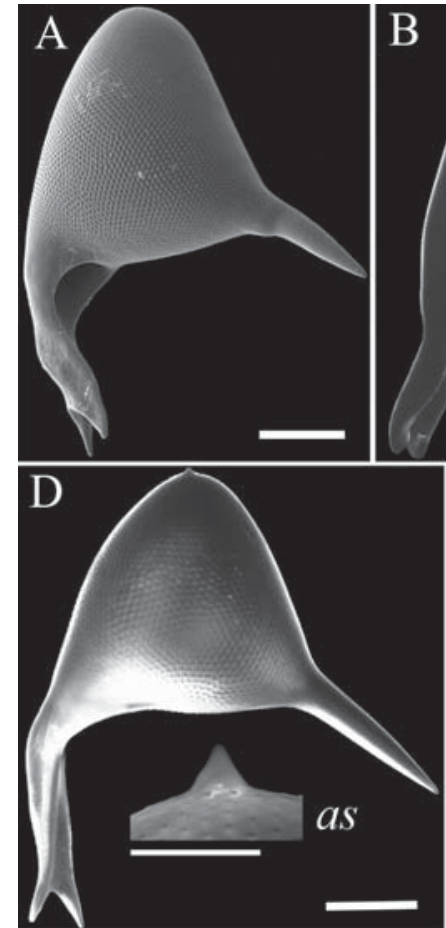
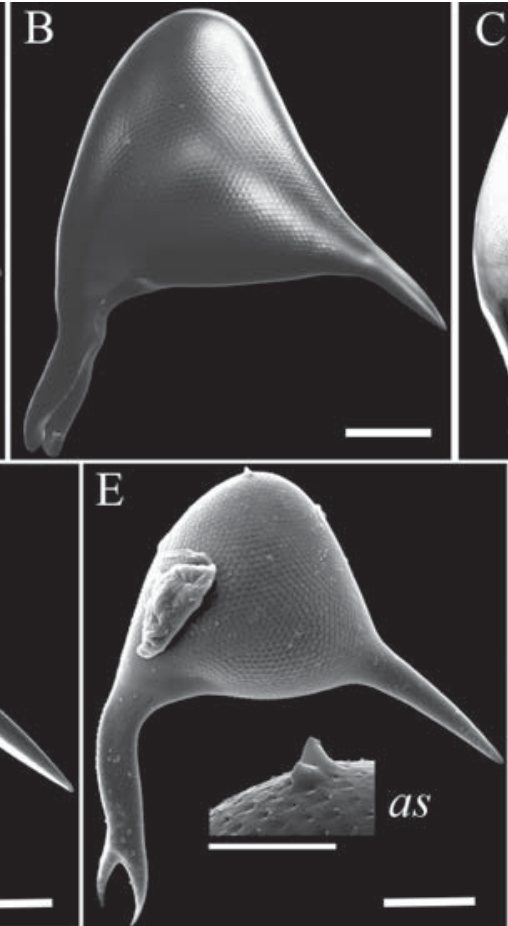
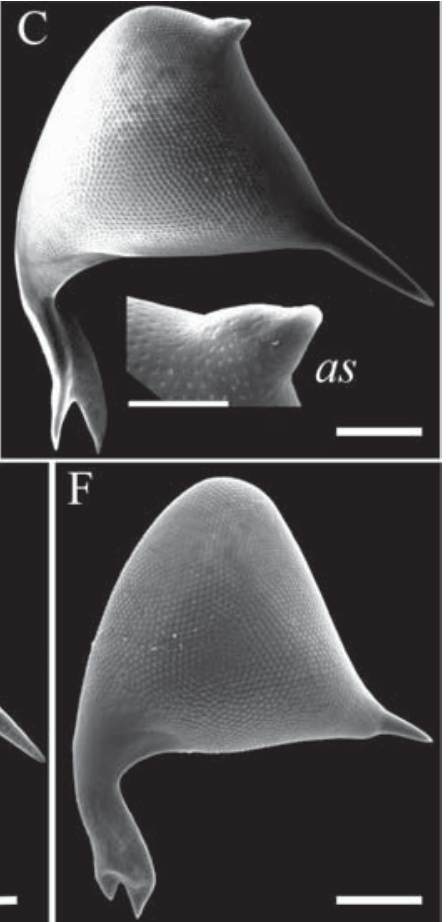

Fig. 3. Shells of Protocystis vicina (A-E) and Protocystis ornitocephala (F); as - detail of apical (aboral dorsal) spine in higher magnification. Scale bars $50 \mu \mathrm{m}$ (20 $\mu \mathrm{m}$ for higher magnification).

Рис. 3. Раковины Protocystis vicina (A-E) и Protocystis ornitocephala (F); as - апикальная (аборально дорсальная) игла под большим увеличением. Масштаб 50 мкм (20 мкм для большего увеличения). 
COMPARISON. This species differs from other species of the Challengeron by the presence of three long spines. A photograph of Challengeron tochilinae was published by $\mathrm{Na}-$ kamura et al. (2015b) as Challengeriidae sp. 2. Challengeron sp. from the Sea of Okhotsk (Okazaki et al., $2004 \mathrm{Pl} .4$, fig. 3, 4) is also similar to the new species but has one more, 4 th spine. A phylogenetic analysis that included these species (as Challengeriidae sp. 2, according to Nakamura et al., 2015b), showed a polyphyly of the genus Challengeron, and, therefore, the new species was attributed to this genus provisionally. Challengeron tochilinae is referred to challengeriid species with very small shell (60-90 $\mu \mathrm{m}$ long), which tend to shallow depths (see Reshetnjak, 1966).

DISTRIBUTION. Sea ofOkhotsk (our data), and Pacific Ocean east of northern Honshu Island (Nakamura et al., 2015b).

\section{Protocystis vicina Reshetnjak in Dogel et Reshetnjak, 1952 \\ Fig. 3 A-E.}

MATERIAL: 13 shells from the Sea of Japan, R/V 'Akademik Lavrentyev', st. B4-4, August 21, 2010, $42^{\circ} 59.8^{\prime} \mathrm{N}, 135^{\circ} 25^{\prime} \mathrm{E}$, multicorer, depth $3381 \mathrm{~m}$. Three shells from the Sea of Japan, st. B4-6, August 21, 2010, 4301' N, $135^{\circ} 26^{\prime}$ E, multicorer, depth $3333 \mathrm{~m}$.

REMARKS. The species was described as having two spines: a long aboral ventral spine and a very short aboral dorsal spine (Dogel, Reshetnjak, 1952). However, Japanese authors have provided images of this species both with and without the aboral dorsal spine (Nakamura et al., 2015b: fig. 1). In the material from bottom sediments of the Sea of Japan, this species is represented by specimens both with an aboral dorsal spine of different shapes and sizes, and without it. In the latter case, these specimens are similar to another species, Protocystis ornitocephala Reshetnjak in Dogel et Reshetnjak, 1952 (fig. 3F, specimen from the Sea of Okhotsk), whose aboral ventral spine is shorter than in P. vicina. The shell shape in the specimens from the Sea of Japan varies from typical of $P$. vicina to more similar to $P$. ornitocephala. It is very likely that $P$. vicina and $P$. ornitoce- phala belong to the same, morphologically variable, species; however, analysis of more extensive materials is needed to resolve this issue.

DISTRIBUTION. The Sea of Okhotsk, the Sea of Japan, the Bering Sea, and the northwestern Pacific Ocean.

\section{Acknowledgements}

I express my sincere thanks to Dr. Demetrio Boltovskoy and anonymous reviewer for their valuable comments, which significantly contributed to the improvement of the manuscript. Author is grateful to Denis V. Fomin for technical assistance with SEM facilities of the Far East Center of Electron Microscopy (NSCMB, FEB RAS, Vladivostok, Russia). I am also grateful to Mr. Evgeniy P. Shvetzov for correcting the English text.

\section{References}

Dogel V.A., Reshetnjak V.V. 1952. [Material on radiolarians of the northwestern part of the Pacific Ocean] // Issledovaniya dalnevostochnykh morei SSSR. Vol.3. P.5-35 [in Russian].

Ishitani, Y., Takahashi K. 2007. The vertical distribution of Radiolaria in the waters surrounding Japan // Marine Micropaleontology. Vol.65. P.113-136.

Nakamura Y., Imai I., Yamaguchi A., Tuji A., Suzuki N. 2013. Aulographis japonica sp. nov. (Phaeodaria, Aulacanthida, Aulacanthidae), an abundant zooplankton in the deep sea of the Sea of Japan // Plankton \& Benthos Research. Vol.8. P.107-115.

Nakamura Y., Imai I., Yamaguchi A., Tuji A., Suzuki N. 2015a. A new phaeodarian species discovered from the Japan Sea proper water, Auloscena pleuroclada sp. nov. (Aulosphaeridae, Phaeosphaerida, Phaeodaria) // Journal of Eukaryotic Microbiology. Vol.63. P.271-274.

Nakamura Y., Imai I., Yamaguchi A., Tuji A., Not F., Suzuki N. 2015b. Molecular phylogeny of the widely distributed marine protists, Phaeodaria (Rhizaria, Cercozoa) // Protist. Vol.166. No.3. P.363-373.

Okazaki Y., Takahashi K., Itaki T., Kawasaki Y. 2004. Comparison of radiolarian vertical distributions in the Okhotsk Sea near the Kuril Islands and in the northwestern North Pacific off Hokkaido Island // Marine Micropaleontology. Vol.51. P.257-284.

Okazaki Y., Takahashi K., Onodera J., Honda M.C. 2005. Temporal and spatial flux changes of radiolarians in the northwestern Pacific Ocean during 1997-2000 // Deep-Sea Research II. Vol.52. P.2240-2274.

Reshetnjak V.V. 1966. [Deepwater radiolarians Phaeodaria of the northwestern part of the Pacific Ocean] // Fauna SSSR. No.94. Phaeodaria. Moscow-Leningrad: Nauka. 208 p. [In Russian]

Responsible editor E.N. Temereva 